\title{
INDIVIDUÁLNÍ INOVAČNÍ CHOVÁNÍ A CHARAKTERISTIKA PRACOVIŠTĚ: POTENCIÁL VÝZKUMU INOVACÍ VE VZDĚLÁVÁNí ${ }^{1}$
}

\author{
INDIVIDUAL INNOVATION BEHAVIOR \\ AND WORKPLACE CHARACTERISTICS: \\ THE POTENTIAL OF INNOVATION \\ SURVEYS IN EDUCATION
}

\author{
GÁBOR HALÁSZ
}

\begin{abstract}
Abstrakt
Inovace vytvoŕené učiteli, učitelskými komunitami a školami v rámci jejich bèžné praxe hrají kličovou roli

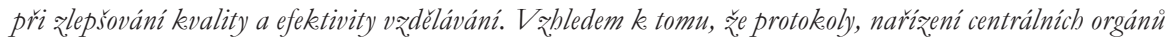
a konvenčni výnkové materiály nemohou obsábnout rèsené věech problémü, keteré se běbem každodenni praxe vyskytnou, je pro vyporádáni se sýzvami, prèed ně̌̌ jsou učitelé a školy v rámci své cinnosti postaveni, nezbytné vytváret nová, originální rèsení. Podobnè jako v jiných profesich náročných na znalosti jsou také pro efektivni práci učiteli a fungováni učitelských komunit nezbytné kereativita a inovativni prístup. $\checkmark$ mnoha zemich jsou školy vybizeny k podpore inovačního pracovního chováni a očekává se od nich, že budou schopny efektivně rídit procesy zmèny a inovací. S rostoucím významem inovací a inovačnich procesù ve vąèláváni vyvstává také otázka, jakým zprisobem inovace v tomto sektoru měrit a jakým zpuisobem mobou data týkajici se inovaci využit ti, kdo rozhoduji. V tomto príspèvku jsou prezentovány některé výsledky prĩzkumu inovaci ve vądélávání, který byl realizován v Mad'arsku v roce 2018. Je v nèm názorně prédstavena možnost navrbnout nástroje pro sbèr dat, které umožnuji zachytit inovačni proces na úrouni školy/katedry. Př́spèvek se zamèruje na jednu konkrétni problematickou oblast, a sice na vz̨tab mez̨i inovačni aktivitou / inovačním chovánim a charakteristikami organizace (pracovišté).
\end{abstract}

Původní verze tohoto příspěvku vznikla jako součást výzkumného projektu s názvem Innova financovaného z prostředků mad’arského Národního institutu pro výzkum, vývoj a inovace (číslo projektu: 115857). 


\title{
Klíčová slova
}

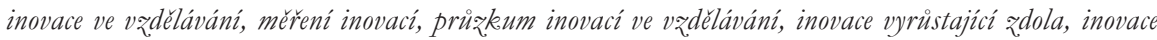
vedené učitelem, organizačni studie ve vądèlávání

\begin{abstract}
Innovations created by teachers, teacher communities, and schools in their daily practices play a key role in improving the quality and effectiveness of education. As protocols, central regulations, and ready-made teaching materials do not provide solutions to all problems emerging in daily practice, it is necessary to invent new and original solutions to respond to the challenges teachers and schools encounter in their everyday work. As in other knowledge-based professions, creativity and innovativeness are necessary skills for teachers and teacher communities so that they can work effectively. In many countries, schools are encouraged to support innovative work behavior and are expected to manage change and innovation processes effectively. The increasing importance of innovations and innovation processes in education raises the question of how to measure innovation in this sector and how decision makers can use innovation data. This article presents some of the outcomes of an education sector innovation survey conducted in Hungary in 2018. It demonstrates the possibility to design data collection instruments that enable capturing school/department-level innovation processes. The article focuses on one specific problem area: the relationship between innovation activity/behavior and organizational (workplace) characteristics.
\end{abstract}

\section{Keywords}

educational innovation, measuring innovation, education sector innovation survey, bottom-up innovation, teacher-led innovations, organizational studies in education

\section{Úvod}

Inovace vytvořené učiteli, učitelskými komunitami a školami v rámci jejich běžné praxe hrají zásadní roli při zlepšování kvality a efektivity vzdělávacího systému. Vytváření nových, originálních řešení - at’ už jednodušších nebo složitějších - je nezbytným předpokladem úspěšného zvládání mnohých výzev, s nimiž se učitelé v rámci své každodenní praxe setkávají. Řešení všech problémů, které s sebou praxe přináší, nelze najít v protokolech, nařízeních centrálních orgánů ani konvenčních výukových materiálech. Podobně jako v jiných profesích náročných na znalosti jsou také pro efektivní práci učitelů a fungování učitelských komunit nezbytné kreativita a inovativní př́stup. V mnoha vzdělávacích systémech se od škol ve stále větší míře očekává podpora inovačního pracovního chování a efektivní rízení procesů změny a inovací.

Jak je upozorňováno $v$ nedávno vydané publikaci věnované inovacím ve vzdělávání, „výzkumné instituce často sledují vládní reformy a iniciativy přicházející shora, ale iniciativy, které mají svůj původ přímo v praxi, zatím výzkumné pozornosti unikaji““2 (Smirnov, 2017, s. 86). Inovacemi vyrůstají-

2 „governmental reforms and top-down initiatives are often monitored by research institutions, but grassroots innovations in education escaped the attention of researchers so far" 
cími zdola, prrímo z praxe, vznikajícími na úrovni škol se ale dlouhodobě zabývají výzkumníci zaměření na organizační nebo také „mikropolitické“ procesy ve vzdělávání (Ball, 2012). Jsou-li pro tento typ inovací, který iniciují učitelé a školy na základní úrovni, vytvořeny odpovídající organizační podmínky a je-li zajištěno vhodné vedení, mohou vést $\mathrm{k}$ významným posunům ve vzdělávacích systémech: často s větším dopadem než některé intervence na makro úrovni, které Fullan označuje za „nesprávnou hnací sílu“ (Fullan, 2011). Jak dokládá řada př́padových studií změn, „profese se vyznačuje schopností a také vůlí změnu vést", a to i v méně rozvinutých vzdělávacích systémech, ve kterých není tradice lokálně iniciovaných změn zakotvena (Shirley, 2016, s. 284).

\section{Inovace vedené učiteli}

Aktuální výzkum $\mathrm{v}$ oblasti inovací a inovačních procesů se $\mathrm{v}$ rostoucí míre zaměřuje na inovace často označované jako iniciované zaměstnanci, vycházejici z praxe nebo inovace vytvořené na pracovišti. Dva výzkumníci zabývající se inovacemi ve své práci věnované inovacím vycházejícím z praxe popisují tento posun následovně: „Realizace inovací byla dříve vnímána obvykle jako lineární proces vedoucí od vědecké práce $\mathrm{k}$ praktické aplikaci inovací. Dnes je však inovace vnímána spíše jako výsledek spolupráce v rámci běžných sociálních a ekonomických aktivit“" (Melkas \& Harmaakorpi, 2012, s. 2). Další dvojice výzkumníků zabývajících se inovacemi definovala tuto formu inovací jako ,určitou obnovu vlastních úkonů zaměstnanců nebo managementu např́iklad tím, že vytvoří a zavedou nové pracovní metody, postupy, produkty nebo služby, přičemž tato obnova pramení z neformálního učení se skrze pracovní procesy v rámci daných úkonư“ (Nilsen \& Ellström, 2012, s. 156). Inovace iniciované zaměstnanci, vycházející přímo z praxe nebo vznikající na pracovišti, jsou označovány také jako „aktuální, rodící se, spontánní, neformální a neplánované“, které „nemusí být součástí explicitní agendy organizace“, ale mohou vést $\mathrm{k}$ „přetvoření každodenní pracovní praxe“ (Høyrup, 2012). O tomto druhu inovací se dále hovoří také jako o „skrytých inovacích“ (NESTA, 2007), což pramení z obtížnosti jejich uchopení a změření a dále z toho, že jsou navzdory svému významu v průzkumech zaměřených na inovace na národní nebo sektorové úrovni obvykle opomíjeny.

Inovace iniciované zaměstnanci, vycházející přímo z praxe nebo vznikající na pracovišti jsou v sektoru vzdělávání často popisovány jako inovace vedené učiteli nebo inovace osnov na úrovni školy. Přehled dokladů toho, že rozvinuté vzdělávací systémy směřují $\mathrm{k}$ modelům zlepšování na základě inovací vedených učiteli, přináší australská studie analyzující relevantní 
politiky a praxe ve čtyřech systémech (Kanada, Anglie, Skotsko a Německo). Jak poznamenává její autor: „výzvou je, jak zapojit učitele do řešení problémů, s nimiž se školy potýkají, do učení se z nově vytvořené praxe a inovací a do následného sdílení profesních znalostí kreativním způsobem, aby z něj mohli mít prospěch všichni““ (Fraser, 2005).

Vybízení učitelů a učitelských komunit, aby $\mathrm{v}$ rámci své běžné praxe nalézali nová, originální řešení, se stalo jedním ze základních prvků vzdělávacích politik vysoce výkonných systémů jihovýchodní Asie: jedním z typických řešení je adaptace japonského modelu tzv. lesson study (viz např́iklad Cheng \& Lo, 2013; Goodwin, 2014). Jedná se o ustálenou formu využívání kreativity a iniciativy zaměstnanců za účelem průběžného zlepšování výkonu organizace, což představuje běžnou praxi v japonských firmách. O inovacích, které vznikají na konkrétní škole a jež jsou iniciovány učiteli v rámci jejich běžné praxe, se v poslední době hovoří jako o vzorci změny, který je nově pozorován na „průměrných“ nebo „neelitních“ školách v Číně (Tan, 2016).

$S$ rostoucím významem inovačního chování a inovační aktivity zaměstnanců $\mathrm{z}$ hlediska zkvalitňování a efektivnějšího fungování systémů a organizací narůstá také potřeba toto chování a tuto aktivitu měřit. Měření inovací a inovačních procesů ve vzdělávacím sektoru se stalo důležitou prioritou $\mathrm{v}$ řadě systémů a na jeho důležitost ve stále větší míře upozorňují také velké mezinárodní instituce (Dunne et al., 2014; OECD, 2014; 2017; VincentLancrin et al., 2019). Spuštění nového průzkumu zaměřeného na inovace ve vzdělávacím sektoru mezi členskými státy před časem navrhla OECD a tato myšlenka se setkala s jednoznačnou podporou také ze strany Evropské komise. $^{3}$

$\mathrm{V}$ tomto př́spěvku prezentujeme výsledky průzkumu zabývajícího se inovacemi ve vzdělávacím sektoru, který byl realizován v Mad’arsku. První výsledky, založené na prvním kole sběru dat na úrovni vzdělávací jednotky, byly prezentovány mezinárodnímu publiku na několika konferencích v Evropě a Asii a byly publikovány v mezinárodních (Halasz, 2018a) a národních odborných časopisech (Fazekas et al., 2018). Tento př́spěvek vychází z výsledků druhého kola sběru dat, které proběhlo jak na úrovni vzdělávacích jednotek, tak také na úrovni jednotlivců (zaměstnanců). Přestože zde prezentovaný průzkum inovací byl proveden $\mathrm{v}$ jed né konkrétní zemi, výsledky, včetně navržených nástrojů pro sběr dat a přístupů použitých při analýze dat, mohou být př́nosné pro mezinárodní publikum obecně. 


\section{Měření inovací ve vzdělávání: mad'arská zkušenost}

Také v Mad’arsku, podobně jako v dalších zemích, se podpora inovačních procesů ve vzdělávacím sektoru stala prioritou politiky v této oblasti. Tato podpora výrazně narostla se vstupem země do Evropské unie v roce 2004, kdy se otevřely také možnosti čerpání finančních prostředků na rozvoj vzdělávání ze strukturálních fondů. Do rozvojových intervencí, které často explicitně vyžadovaly vytvoření inovací na úrovni školy nebo tř́idy, se zapojily tisíce vzdělávacích jednotek a učitelů (Fazekas, 2018; Halász, 2018b). $\mathrm{K}$ určitému nasměrování podpory inovací ve vzdělávání posloužily mimo jiné také dokumenty týkající se strategie inovací ve vzdělávacím sektoru (Balázs et al., 2015; NIERD, 2011). Důležitým prvkem navrhovaným těmito strategiemi je vývoj nástrojů k měření inovačních procesů ve vzdělávání. Jedním z cílů výzkumného projektu Innova, který byl spuštěn v roce 2016, je právě vytvoření takových nástrojů a dále analýza dynamiky inovačních procesů ve vzdělávání s využitím dat shromážděných pomocí těchto nástrojů.

\section{Teoretický rámec výzkumného projektu Innova}

Klíčové prvky teoretického rámce projektu Innova byly prezentovány v jiných publikacích (viz např́klad Halasz, 2018a). Souhrnně se dá říci, že v rámci tohoto projektu je zvolen př́stup, kdy jsou inovace a inovační procesy nahlíženy současně ze čtyř různých hledisek: (1) inovace vnímaná jako produkt; (2) vznik inovací; (3) činitelé zapojení do vytváření/zavádění inovací; a (4) šíření nebo rozptyl inovací. Tyto čtyři perspektivy byly doplněny o dimenzi času a prostoru. Nástroje pro sběr dat byly vytvořeny na základě použití kombinace ,př́ístupu zaměřeného na subjekt a na objekt“", který byl podpořen vydáním Oslo manuálu (OECD/Eurostat, 2018) a použit také v několika studiích inovací (Arundel et al., 2016a; 2016b).

Výzkumný projekt Innova se zaměřuje na inovace vytvořené a aplikované školami, učiteli a učitelskými týmy, tedy inovace vznikající na základní úrovni neboli vyrůstající zdola. Použita byla jednoduchá a pragmatická definice inovace: inovace byla pojata jako odchylka od běžné praxe s cílem dosáhnout lepších výsledků. Klíčovým konceptem, kterým se řídil design sběru 
dat, byl „inovační trojúhelník“ inspirovaný Engeströmovou teorií činnosti (Engeström, 1999a; 1999b). Inovační trojúhelník se skládá se tř́i komponent: (1) specifika problémů nebo problematických situací, které se objevují v každodenní profesní praxi; (2) kognitivní procesy použité v rámci procesu řešení problémů; a 3) interakce aktérů zapojených do procesu řešení problémů. Z tohoto hlediska byla inovace často definována jako vypořádávání se s pracovními problémy vyžadujícími nová řešení.

Základním předpokladem výzkumného projektu Innova je pojetí inovace jako přirozené součásti práce kohokoli, kdo se potýká s výzvami a komplexními úkoly, což učitelé bezpochyby naplňují. Z tohoto důvodu se právě výzkum zaměřený na inovace iniciované zaměstnanci, vycházející z praxe nebo vznikající na pracovišti, jeví v tomto kontextu jako zvlášt' relevantní. Dalším základním předpokladem je, že inovační chování a inovační aktivita jednotlivců je výrazně podmíněna organizací, ve které pracují. Tento příspěvek si klade za cíl, s využitím dat získaných v rámci projektu Innova, podrobit zkoumání složitý vztah mezi inovačním chováním a inovační aktivitou jednotlivců na straně jedné a organizačními charakteristikami jejich pracoviště na straně druhé.

\section{Průzkum inovací ve vzdělávání Innova}

Jedním z úskalí, se kterými bylo třeba se při navrhování nástrojů průzkumu Innova vypořádat, byl záměr vytvořit jeden nástroj pro celý vzdělávací sektor, čili dotazníky, které by bylo možné použít na všech úrovních od mateřských škol, přes základní a střední školy až po katedry vysokých škol a doktorské programy, včetně soukromých posky tovatelů odborného vzdělávání v sektoru vzdělávání zaměřeném na odborné vzdělávání dospělých. Vytvořeny byly dva typy dotazníků: jeden pro vedoucí stojící v čele vzdělávacích jednotek (dotazník pro organizace) a druhý určený učitelům pracujícím v těchto jednotkách (dotazník pro jednotlivce).

První sběr dat byl proveden s využitím první verze dotazníku pro organizace na podzim roku 2016 a druhé kolo, ve kterém byla použita druhá verze dotazníku pro organizace a nový dotazník pro jednotlivce (zaměstnance), bylo realizováno na jaře roku 2018. V obou př́padech byly rozeslány e-mailové zprávy ředitelům všech vzdělávacích jednotek v Mad’arsku (téměř 18000 jednotek). Prostřednictvím e-mailu jsme vyzvali ředitele, aby vyplnili dotazník určený organizacím a předali pozvánku k zodpovězení dotazníku určeného jednotlivcům dalším pracovníkům v jejich organizaci. Výsledkem obou sběrů dat bylo několik datových sad, které byly sloučeny do dvou komplexních datových sad prezentovaných v tabulce 1 . 
Tabulka 1

Data sloučená do dvou datových sad Innova

\begin{tabular}{|c|c|c|c|c|c|}
\hline \multicolumn{2}{|c|}{ Datová sada za organizaci (pracoviště) } & \multicolumn{3}{|c|}{ Datová sada za jednotlivce (zaměstnance) } \\
\hline $\begin{array}{c}\text { Data } \\
\text { z roku 2016 }\end{array}$ & $\begin{array}{c}\text { Data } \\
\text { z roku 2018 }\end{array}$ & $\begin{array}{c}\text { Agregovaná } \\
\text { individuální } \\
\text { data } \\
\text { z roku 2018 }\end{array}$ & $\begin{array}{c}\text { Data za } \\
\text { jednotlivce } \\
\text { z roku 2018 }\end{array}$ & $\begin{array}{c}\text { Data za } \\
\text { organizaci } \\
\text { z roku 2016 }\end{array}$ & $\begin{array}{c}\text { Data za } \\
\text { organizaci } \\
\text { z roku 2018 }\end{array}$ \\
\hline $\mathrm{N}=4853$ & $\mathrm{~N}=1942$ & $\mathrm{~N}=1194$ & $\mathrm{~N}=4025$ & $\mathrm{~N}=873$ & $\mathrm{~N}=2222$ \\
\hline
\end{tabular}

Poznámky: V př́ípadě datové sady za organizaci (pracoviště) označuje pojem „agregovaná individuální data“" průměrnou hodnotu odpovědí jednotlivců pracujících v dané organizaci, přičemž se jedná o škálové proměnné. $V$ př́ipadě datové sady za jednotlivce (zaměstnance) pojem „data za organizaci“ představuje odpovědi vedoucího organizace, ve které je daný jednotlivec zaměstnán (tato hodnota je přidána ke každému záznamu za jednotlivce, je-li k dispozici).

Díky těmto komplexním databázím je možné provést různé analýzy, včetně analýz sledujících dvě úrovně zároveň (hierarchické analýzy). V tomto př́ispěvku používáme pouze individuální databázi a sledujeme inovační aktivitu/chování jednotlivých učitelů. Data za organizaci nebo pracoviště - získaná od vedoucích organizací, ve kterých zapojení jednotlivci pracují slouží jako kontextové proměnné v návaznosti na individuální data, a sice vedle dat kontextových proměnných získaných od jednotlivých respondentů. Použití těchto dat popisujících kontext pracoviště, na kterém se inovační činnost učitelů odehrává, umožňuje zkoumání možného vlivu charakteristik pracoviště na inovační chování a aktivitu učitelů.

Jak již bylo zmíněno, použita byla kombinace př́stupů zaměřujících se na subjekt a na objekt. Respondenti z řad učitelů byli vyzváni $\mathrm{k}$ zodpovězení dvou skupin otázek souvisejících s jejich inovační praxí. Otázky náležející do první skupiny jsou obecné: nesouvisí s konkrétní, specifickou inovací (např. „Zúčastnilla jsem se programu, v rámci něbožjsem mèll/a vytvorit nové osnovy, výukové nástroje a pedagogické metody“). Otázky z druhé skupiny se váží k jedné specifické, konkrétní inovaci, kterou respondent vytvořil a vybral si ji pro další zkoumání. $\mathrm{V}$ tomto př́spěvku analyzujeme vztah mezi inovačním chováním / inovační aktivitou jednotlivců a organizačním kontextem, ve kterém

$5 \quad$ Později byl realizován ještě třetí sběr dat založený na osobních rozhovorech se 100 vedoucími vzdělávacích jednotek a 200 zaměstnanci těchto jednotek. Data z tohoto třetího kola nejsou v tomto př́spěvku zohledněna. 
pracují, prričemž používáme pouze data těch respondentů, kteří byli ochotni vybrat a představit jednu ze svých konkrétních inovací. Pro použití této omezené databáze $(\mathrm{N}=1353)$ jsme se rozhodli na základě předpokladu, že lidé ochotní prezentovat podrobněji některou ze svých konkrétních inovací by mohli patřit mezi nejspolehlivější respondenty.

\section{Indikátory individuální inovační aktivity a individuálního inovačního chování}

V této studii používáme dva indexy individuálních inovací vypočítané na základě dotazníku pro jednotlivce $\mathrm{v}$ rámci průzkumu Innova. Jeden z nich odkazuje k tomu, co označujeme jako inovační chování, a druhý k tomu, co nazýváme inovačni aktivitou. Tyto pojmy pro nás představují dvě kategorie. Inovační chování můžeme definovat jako sadu postojů, sklonů a souvisejících forem jednání. Inovační aktivita označuje intenzitu nebo frekvenci, s níž lidé ve své práci uplatňují inovační řešení. Indikátory inovačního chování umožňují vytvoření typologie jako nástroje klasifikace jednotlivců podle jejich postojů a sklonů souvisejících s inovacemi. Lidé přiřazení $\mathrm{k}$ těmto kategoriím mohou vykazovat různé stupně skutečné inovační aktivity.

\section{Index inovačního chování}

K měření inovačního chování používáme zjednodušenou verzi nástroje, který původně vytvořili autoři de Jong a Den Hartog (2008) a který byl následně přizpůsoben pro potřeby vzdělávacích institucí výzkumníky Messmann a Mulder (2012). Tento zjednodušený nástroj, pưvodně známý pod názvem škála Inovačního pracovního chování (Innovation Work Behaviour - IWB), se skládá z 12 tvrzení ohledně různých činností souvisejících s inovacemi. Respondenti měli uvést frekvenci těchto činností v rámci své praxe na Likertově škále 1-7. Explorační faktorová analýza odhalila dva nezávislé faktory IWB: jeden související s kreativitou a produkováním myšlenek a druhý související se zaváděním nebo realizací myšlenek. V rámci této studie byla použita analýza hlavních komponent se zadáním dvou faktorů. Tyto dva (nezávislé) faktory objasňují $67 \%$ variability. Tabulka 2 ukazuje korelaci těchto dvou faktorů s položkami testu. 
Tabulka 2

Inovačni pracovni chováni respondentů (korelačni matice faktorü)

\begin{tabular}{|l|c|c|}
\hline & Faktor 1 & Faktor 2 \\
\hline Získání souhlasu s realizováním nových myšlenek & 0,833 & 0,201 \\
\hline Vyhledávání podporovatelů realizace nových myšlenek & 0,808 & 0,217 \\
\hline $\begin{array}{l}\text { Vybízení členů personálu, kteří mají v instituci důležitou roli, } \\
\text { k uplatńování nových nápadů }\end{array}$ & 0,787 & 0,219 \\
\hline Podstupování rizika s cílem dosáhnout slibných řešení & 0,734 & 0,334 \\
\hline Systematické zavádění nových řešení v pracovním kontextu & 0,718 & 0,420 \\
\hline Převádění nových myšlenek do podoby praktických řešení & 0,703 & 0,445 \\
\hline Vyhodnocování užitečnosti nových myšlenek & 0,664 & 0,452 \\
\hline Sledování vývoje v institucích obdobného charakteru & 0,635 & 0,373 \\
\hline Nalézání nových pracovních metod, technik a nástrojů & 0,260 & 0,832 \\
\hline Nalézání nových myšlenek v náročných oblastech & 0,293 & 0,790 \\
\hline Vytváření originálních řešení pro konkrétní problematické situace & 0,348 & 0,755 \\
\hline Sledování vývoje v mém oboru & 0,235 & 0,684 \\
\hline
\end{tabular}

Faktor 1 označujeme jako „implementační chování“ a faktor 2 jako „,kreativní chování“. Faktorová skóre byla pro účely usnadnění porovnání převedena na škálu 1-100. Obě nové proměnné se vyznačují rozložením blížícím se normálnímu a vykazují také poměrně vysokou míru vnitřní konzistenci položek. ${ }^{6}$

\section{Index inovaćni aktivity}

Dotazník pro jednotlivce průzkumu Innova obsahoval řadu otázek směřujících k zjištění intenzity inovační aktivity respondentů. Respondenti byli požádáni o uvedení četnosti určitých forem akce v rámci jejich praxe za posledních deset let. Četnost byla vyjádřena pomocí škály, kde byla odpovědi „,tento případ nikdy nenastal“ přiřazena hodnota 1 a odpovědi „tento případ nastal mnohokrát“ hodnota 4. Odpovědi na uvedené otázky byly použity i pro účely výpočtu složeného ukazatele inovační aktivity (CII). V tomto př́padě jsme při vytváření ukazatele zohlednili teoretické úvahy (OECD, 2008). $\mathrm{K}$ výpočtu hodnoty složeného indexu bylo použito pouze několik položek dotazníku a hodnota indexu byla založena na výpočtech prostého průměru a statistickém vážení založeném na teorii.

$6 \quad$ Sikmost $=0,013 \mathrm{a}-0,197$; špičatost $=-0,412 \mathrm{a}-0,007 . \mathrm{N}=1318$. Cronbachova alfa je 0,81 pro položky s vyšším skóre faktoru 1 a 0,64 pro položky s vyšším skóre faktoru 2 . 
Primární hodnota ukazatele byla vypočtena jako prostý průměr hodnoty následujících čtyř položek:

- „Objevilla a začalla jsem použivat nová rešení, která se výraznè lišila od mép predchozípraxe."

- „Začalla jsem použivat rèéení, keterá se vírazně lišila od mé predchozí praxe a o kterých jsem se dozvédéll a od ostatnich."

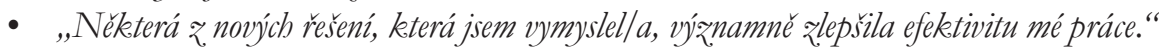

- „Experimentoval/a jsem s novými rešenimi a metodami, které mi pomobly v mé vlastni práci."

Primární hodnota CII byla zvýšena (vážením) v závislosti na výskytu následujících konkrétních charakteristik.

1. Zvlášt' vysoká četnost třetí z výše uvedených položek, která je z hlediska toho, jak chápeme pojem inovační aktivita, nejvýznamnější

2. Vysoká četnost inovací v několika konkrétních oblastech uvedených níže:

- Metody a nástroje pro plánování a implementaci vyučovacích hodin

- Vyhodnocení nebo měření výsledků studentů

- Aktivity mimo školní tř́́du nebo výuku

- Technická a IT řešení ve výuce

- Interní organizace pracoviště

- Technická a IT řešení ovlivňující vedení a řízení organizace

- Vnější vztahy s partnery/uživateli

- Rozvoj kompetencí a schopností žáků/studentů

- Nová řešení pro rozvoj talentů

- Vzdělávání znevýhodněných žáků/studentů nebo žáků/studentů se speciálními vzdělávacími potřebami

3. Vysoká četnost určitých aktivit spojených s přenosem inovací, např́klad replikace řešení vytvořených respondentem kolegy v rámci dané instituce nebo z jiných institucí

4. Podrobná prezentace jedné konkrétní inovace (v dotazníku byla tato položka volitelná)

I když cílem výzkumného projektu Innova nebylo hodnocení obecné úrovně inovační aktivity mad’arských učitelů (náš vzorek nepředstavuje celek pracovní síly učitelské profese na národní úrovni), relativně vysoký počet odpovědí z různých dílčích sektorů vzdělávacího systému umožňuje vytvořit si přibližnou představu o intenzitě individuální úrovně inovační aktivity v mad’arském vzdělávacím systému. Jak je patrné z obrázku 1, rozložení jednotlivců s nižší a vyšší mírou inovační aktivity - měřeno naším indexem CII - se blíží normálnímu rozložení (podobně jako v př́ípadě dvou proměnných inovačního chování). Vnitřní konzistence indexu CII je poměrně vysoká: Cronbachova alfa vypočítaná na základě položek definujících neváženou hodnotu indexu je 0,79 . 


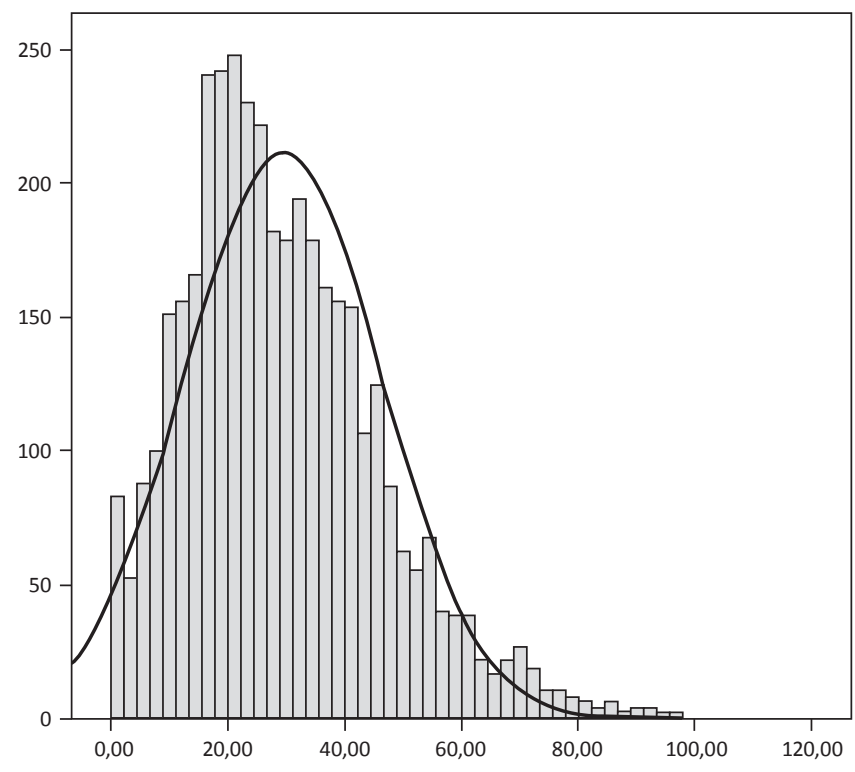

Obrázek 1

Individuální složený index inovačni aktivity (CII)

Poznámka: Hodnoty indexu inovační aktivity CII jsou v rozmezí 0 až 100 (průměr = 29,1; směrodatná odchylka $(\mathrm{SD})=16,7)$.

Jak bylo uvedeno, respondenti v průzkumu Innova byli vyzváni, aby zvolili jednu konk rétní inovaci, kterou vytvořili, a odpověděli na několik konk rétních otázek, jež se $\mathrm{k}$ ní vázaly. $Z$ více než 4000 respondentů více než 1300 souhlasilo s prezentováním jedné konkrétní inovace, kterou vytvořili (34\%). Není překvapivé, že CII těchto respondentů je výrazně vyšší než index respondentů, kteří nemohli nebo nechtěli prezentovat žádnou svoji konkrétní inovaci. Jak již bylo zmíněno, v této studii se zaměříme na analýzu vztahu mezi kontextovými faktory a individuální inovační praxí na tomto omezeném vzorku.

\section{Inovační chování a inovačni aktivita}

Inovační aktivita a inovační chování nejsou na sobě nezávislé. Respondenti vykazující vyšší hodnotu u obou ukazatelů IWB zároveň dosahují vyšších skóre CII, a sice v obou oblastech IWB (implementace a kreativita). Existence dvou ukazatelů IWB umožňuje vytvoření typologií. Respondenty, kteří nevykazují kreativní ani implementační chování, označujeme jako „rutinéry“. Respondenty, kteří vykazují obě tyto kvality, označujeme jako „inovátory“. Respondenti, kteří vykazují kreativitu bez implementačního chování, 
označujeme jako „snílky“ a respondenty s opačnou kombinací označujeme jako „manažery“. Na obrázku 2 jsou zobrazena skóre CII osob náležejících k uvedeným čtyřem typům, samostatně pro respondenty, kteří prezentovali vlastní konkrétní inovaci, a ty, kteří ji neprezentovali. Rozdíly ve skóre CII „snílkưu a „manažerư“ nejsou statisticky významné, ostatní rozdíly ale statisticky významné jsou.
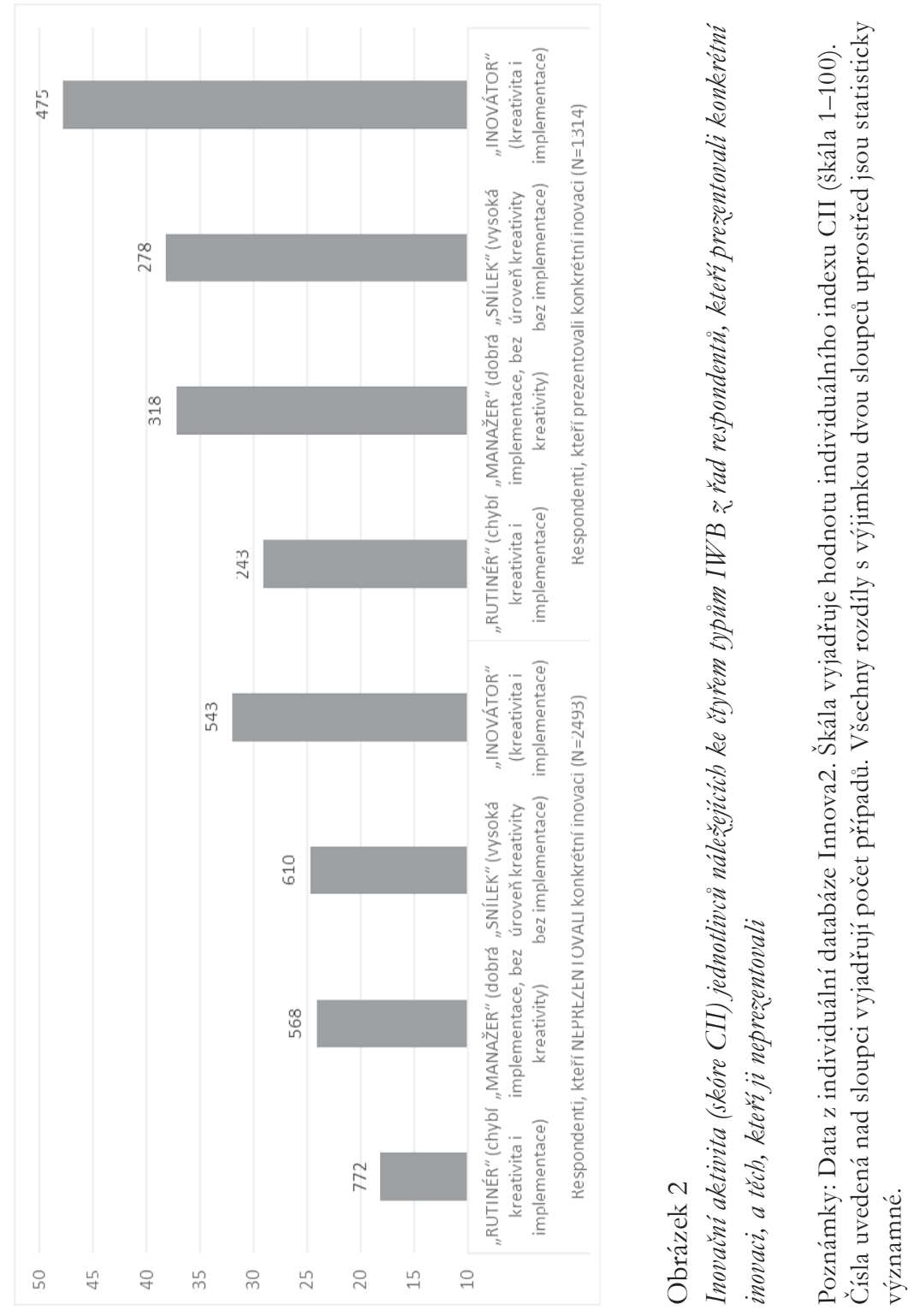
Obrázek 2 také ukazuje rozdíl ve skóre individuálního indexu CII mezi respondenty prezentujícími konkrétní inovaci a těmi, kdo ji neprezentovali. V následující části pokračujeme v analýzách pouze v rámci první skupiny těch, kdo byli ochotni vybrat jednu ze svých inovací a poskytnout data o této konkrétní inovaci. Celkový počet případů v této skupině je 1353: 79 \% z nich jsou respondenti ze sektoru K-12, 16 \% z institucí vyššího vzdělávání a 4,3 \% z dalších sektorů.

\section{Individuální inovační chovánílaktivita a charakteristiky pracoviště}

Zatímco v předchozí části jsme se věnovali „závislým proměnným“, v této části se budeme zabývat jejich vztahem k charakteristikám organizace (pracoviště). Dotazníky průzkumu Innova obsahují několik sad otázek souvisejících s organizačními charakteristikami. V této studii jsme pro analýzu vybrali tři oblasti: (1) inovační aktivita organizace (generování inovací na úrovni organizace); (2) dynamická kapacita organizace (pracoviště fungující jako učící se organizace); a (3) obecný organizační profil daných organizací. Pokud jde o první oblast, používáme otázky vytvořené v rámci výzkumných projektů Innova. Ve zbývajících dvou oblastech využíváme převzaté a zjednodušené verze známých nástrojů určených pro výzkum organizací. Ve všech př́padech používáme data, která nám poskytli vedoucí vzdělávacích jednotek (předškolní zařízení, školy, univerzitní katedry), ve kterých jednotlivci zapojení do průzkumu (učitelé, školitelé) pracují.

\section{Inovačni aktivita na úrovni jednotlivce a organizace}

Skóre inovační aktivity na úrovni organizace (pracoviště) bylo vypočteno obdobným způsobem jako individuální index CII. Tato proměnná popisující znaky organizace je zároveň složenou proměnnou vycházející z teoretických hledisek. Index CII organizace je založen na podobných otázkách, které se však v tomto př́padě nevztahují k jednotlivci, ale k organizaci, přičemž na otázky odpovídali vedoucí příslušných organizací. Učitelé pracující v organizaci s vyšší mírou inovační aktivity vykazovali výrazně vyšší skóre individuálního indexu CII. Průměrný index CII učitelů pracujících v organizaci, která náleží k třetině subjektů s nejnižší organizační inovační aktivitou, je 36,1 ( $\mathrm{N}=199)$. Učitelé pracující v organizacích, které náleží $\mathrm{k}$ třetině s nejvyšší inovační aktivitou, dosáhli skóre 41,9 ( $\mathrm{N}=235)$. Úroveň inovační aktivity organizace může mít vliv nejen na inovační aktivitu jednotlivých učitelů, ale také na jejich inovační chování (IWB), přestože tento vliv se zdá být menší. Mezi skóre IWB učitelů pracujících v organizacích s nižší mírou inovační aktivity jsme oproti učitelům z organizací s vyšší mírou inovační aktivity nezaznamenali statisticky významný rozdíl. 
$\mathrm{Na}$ základě dat o inovačním pracovním chování jednotlivců a úrovni inovační aktivity organizace je možné vytvořit další čtyři skupiny odrážející specifické konstelace na pracovištích. K označení první skupiny jsme použili metaforu „prázdné železné schránky“. Vztahuje se na případy, kdy se jednotlivec s nízkým průměrným skóre inovačního chování nachází v instituci, která vykazuje nízkou úroveň inovační aktivity. Jako "perlu v želez̧né schránce" označujeme př́pady, kdy jednotlivec s vysokým průměrným skóre IWB pracuje v organizaci s nízkou úrovní inovační aktivity. Př́pady, kdy jednotlivec s nízkým průměrným skóre IWB pracuje $\mathrm{v}$ organizaci s vysokou úrovní inovační aktivity, označujeme pomocí metafory „prázdné škeble“. Konečně pak konstelace, kdy jak průměrné skóre IWB jednotlivce, tak úroveň inovační aktivity pracoviště dané osoby dosahují vysokých hodnot, nazýváme „perlou ve škebli“. Na obrázku 3 jsou zobrazena skóre CII jednotlivců náležejících $\mathrm{k}$ těmto čtyřem skupinám.

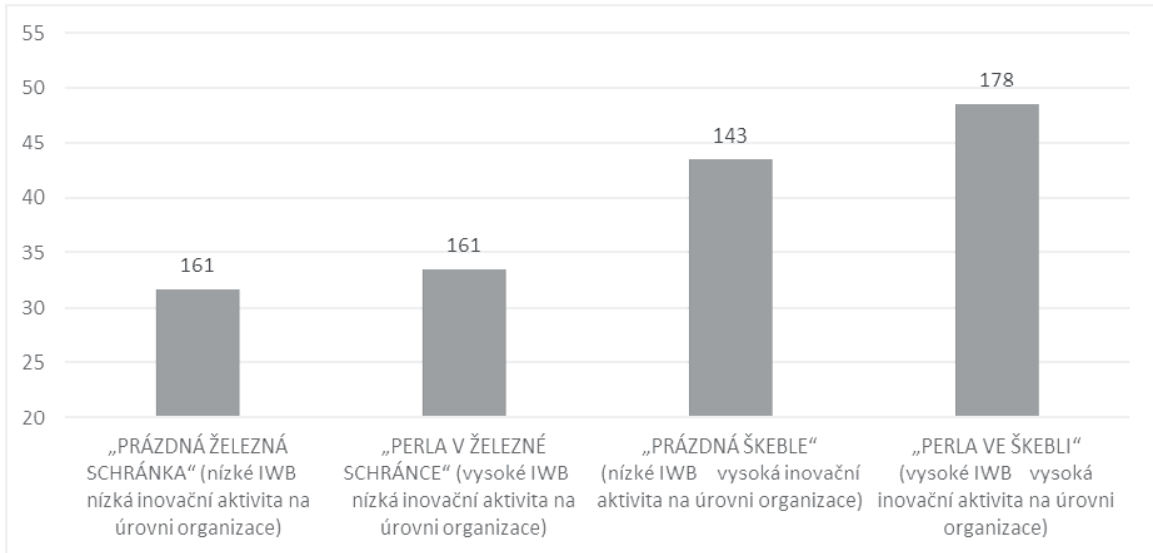

Obrázek 3

Inovačni aktivita (skóre CII) jednotlivcu nále ̌̌ejicićch ke čtyrèm kombinacím IWB a inovační aktivity na úrovni organizace

Poznámky: Data z individuální a organizační databáze Innova2. Škála vyjadřuje hodnotu individuálního indexu CII (škála 1-100). Č́sla uvedená nad sloupci vyjadřují počet př́ípadů. Všechny rozdíly s výjimkou rozdílů mezi osobami náležejícími k „prázdné železné schránce“ a „prázdné škebli“ jsou statisticky významné. Není nijak překvapivé, že situace označená jako „perla ve škebli““ se zdá být nejpř́íznivějšš pro projevení vysoké míry individuální inovační aktivity. 


\section{Individuální inovační chovánílaktivita a dynamické kapacita organizací}

Pojem „dynamická kapacita“ používáme k popisu schopnosti organizací vystupovat jako inteligentní učící se organizace. Dynamická kapacita organizace byla $\mathrm{v}$ rámci našeho sběru dat $\mathrm{v}$ roce 2016 změřena na základě testu převzatého ze zjednodušené verze dotazníku s názvem „Dimenze učící se organizace" (DLOQ), který původně vytvořili autoři Marsick a Watkins (2003; Bess et al., 2010; Horváth, 2017; Horváth \& Halász, 2017; Song et al., 2013; Yang et al., 2004). Respondenti (vedoucí vzdělávacích jednotek) byli požádáni, aby vyjádřili souhlas se 14 tvrzeními ve vztahu ke svým organizacím.

Faktorová analýza hlavních komponent (s rotací varimax) provedená na organizační databázi ${ }^{7}$ vyústila ve tři faktory s vlastními čísly vyššími než 1 , objasňující 60 \% variability. Faktor 1 byl interpretován jako lidé „pracující $\mathrm{v}$ organizacích s vysokou mírou vnitřní koherence, které jsou otevřené vnějšímu prostředí“ (označen jako „koherence/otevřenost"). Faktor 2 byl pak interpretován jako lidé „pracující v organizacích, které podporují učení se a práci svých zaměstnancư“ (označen jako „podpora učení se a práce“) a faktor 3 jako lidé „pracující v organizacích s kulturou nakloněnou učení se“ (označen jako „kultura učení se“). Faktorová skóre (pro účely usnadnění porovnání převedená na škálu 1-100) byla použita jako nové proměnné interpretované jako dimenze učící se organizace.

Data dokládají, že jednotlivci pracující v organizacích s vyšší úrovní dynamické kapacity (jejich pracoviště se více blíží organizacím, které označujeme jako učící se organizace) vykazují mírně vyšší úroveň inovační aktivity. Osoby pracující v organizacích náležejících $\mathrm{k}$ horní třetině organizací podle kombinovaného indexu (průměr tř́ faktorových skóre uvedených $\mathrm{v}$ předchozím odstavci) jsou významně aktivnějšśi ve vytváření inovací v rámci své běžné činnosti než osoby pracující v organizacích náležejících ke spodní třetině (viz obrázek 4).

Pro účely této analýzy byly zahrnuty pouze organizace jednotlivců, kteří prezentovali jednu ze svých konkrétních inovací. Do faktorové analýzy bylo zahrnuto celkem 436 organizací. 


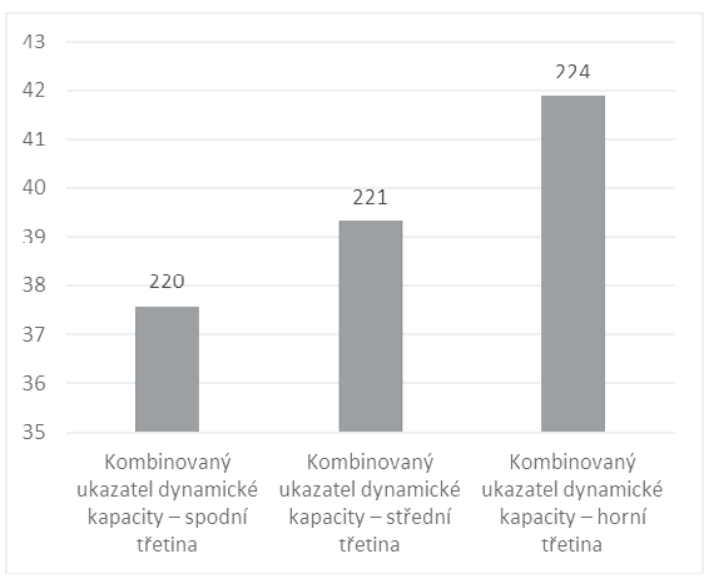

Obrázek 4

Úroveř inovačni aktivity jednotlivcu pracujicich v rïných organizačnich prostrédích

Poznámky: Data z individuální databáze Innova2 a organizační databáze Innova1. Škála vyjadřuje hodnotu individuálního indexu CII (škála 1-100). Č́sla uvedená nad sloupci vyjadřují počet případů. Rozdíly mezi spodní a horní třetinou jsou statisticky významné.

Pokud ale rozložíme kombinované ukazatele na jednotlivé komponenty, získáme diferencovanější pohled. Zdá se, že existuje pouze jedna dimenze učící se organizace, která má jednoznačně kladný lineární vztah k úrovni inovační aktivity jednotlivců: osoby pracující v organizacích, které - dle interpretace vedoucích zastupujících danou organizaci - poskytují vyšší míru podpory učení a práce svých zaměstnanců, jsou významně aktivnější ve vytváření inovací než pracovníci v organizacích, jejichž vedoucí uvádějí, že tento druh podpory je na nízké úrovni. Je pozoruhodné, že mezi inovační aktivitou jednotlivců a faktorem interpretovaným jako vnitřní koherence kombinovaná s otevřeností k okolnímu světu existuje mírná (statisticky nevýznamná) negativní korelace. Zdá se, že jednotlivci pracující v organizacích, které jejich vedoucí charakterizovali jako organizace s vysokou mírou vnitřní koherence a velkou otevřenosti směrem ven, jsou ve vytváření inovací méně aktivní než jejich kolegové z jiných, méně koherentních a více do sebe uzavřených organizací. Obdobný vzorec lze vysledovat také v souvislosti s tím, co jsme nazvali kulturou učení se. Zdá se, že pracovníci v organizacích, které podle svých vedoucích mají zvlášt' rozvinutou kulturu běžně chápanou jako př́iznivou pro učení se, vykazují z hlediska vytváření inovací menší míru aktivity než jejich protějšky z organizací se střední úrovní kultury učení se (viz obrázek 5). 


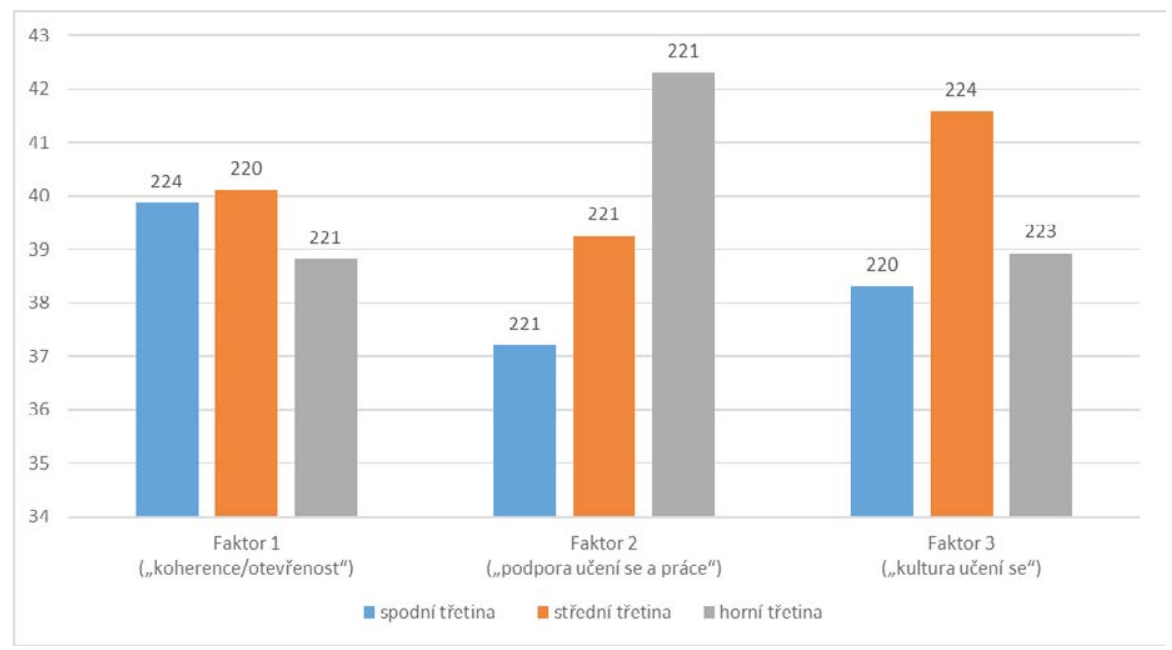

Obrázek 5

Úroveñ inovačni aktivity jednotlivcu (skóre CII) pracujicich v rüzných organizačních prostredích

Poznámky: Data z individuální databáze Innova2 a organizační databáze Innova1. Škála vyjadřuje hodnotu individuálního indexu CII (škála 1-100). Č́sla uvedená nad sloupci vyjadřují počet př́padů. Rozdíly, které lze přičíst faktoru „koherence/otevřenosti“, nejsou statisticky významné. Rozdíly mezi spodní a horní třetinou v „podpoře učení se a práce“ jsou statisticky významné a stejně tak rozdíly mezi spodní a střední třetinou, pokud jde o „kulturu učení se“.

Je důležité zdůraznit, že obrázek 5 znázorňuje inovační aktivitu jednotlivců. Podíváme-li se na inovační aktivitu organizací (vzdělávacích jednotek), situace je odlišná. Inovační aktivita organizací vykazuje pozitivní korelaci se všemi třemi ukazateli organizačního dynamismu. Zodpovězení otázky, proč lidé pracující v organizacích s nejvyšší úrovní „kultury učení se“ vykazují nižší úroveň inovační aktivity ve srovnání s těmi, kdo pracují v organizacích náležejících ke střední třetině (viz pravá strana obrázku 5), není snadné. Jedná se o osoby, jejichž vedoucí se domnívají, že jejich zaměstnanci jsou zvlášt' „otevřeni poskytování a přijímání upř́ímné zpětné vazby“, jsou zvlášt’ připraveni „otevřeně diskutovat o chybách, aby se z nich poučili“ a „přistupovat $\mathrm{k}$ pracovním problémům jako $\mathrm{k}$ př́ležitostem $\mathrm{k}$ učení se a rozvoji“.

Pokud jde o vztah mezi inovačním pracovním chováním (IWB) jednotlivců a dynamickou kapacitou organizace, která se vztahuje na jejich pracoviště, pozorujeme silnější spojitosti, které jsou však mírně odlišné z hlediska dvou typů IWB. Jak je parné z obrázku 6 , jednotlivci v organizacích s vyšší 
úrovní dynamické kapacity vykazují vyšší míru „kreativního chování. Podobně jako v př́ipadě indexu CII je spojitost s faktorem vnitřní koherence a otevřenosti vůči vnějšímu světu slabá (statisticky nevýznamná), silnější je pak spojitost s faktorem podpory iniciativy a učení se zaměstnanců.

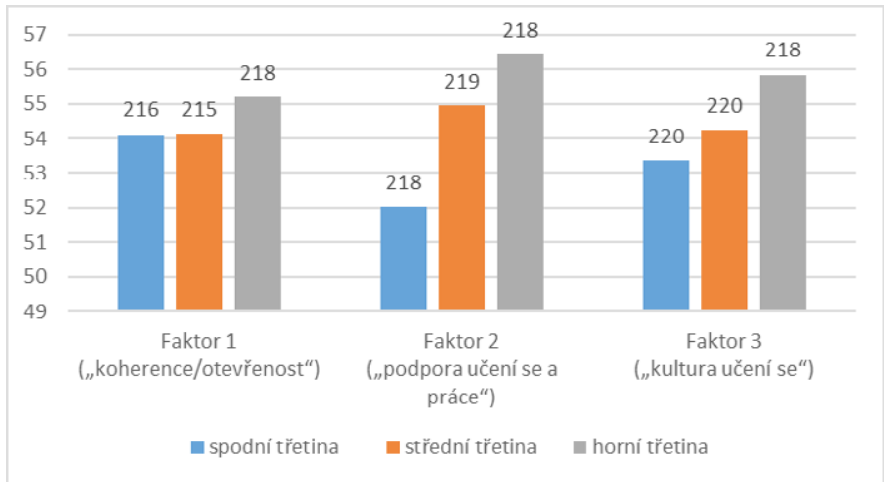

Obrázek 6

Skóre kereativního chování jednotlivcu pracujicich v rïných organizačnich prostredich

Poznámky: Data z individuální databáze Innova2 a organizační databáze Innova1. Škála vyjadřuje hodnotu skóre kreativního chování jednotlivců (škála 1-100). Čísla uvedená nad sloupci vyjadřují počet případů. Rozdíly mezi spodní a střední třetinou v „podpoře učení se a práce“ a rozdíly mezi spodní a horní třetinou, pokud jde o „kulturu učení se“, jsou statisticky významné.

Také hodnoty ukazatele „implementačního chování byly v případě pracovníků v organizacích s vyšší úrovní dynamické kapacity vyšší. Zajímavým výsledkem je, že úroveň tohoto typu inovačního chování je stejná u osob pracujících v organizacích reprezentujících střední a horní tretinu hodnot faktorů „podpora učení se a práce“ a „kultura učení se“ (viz obrázek 7). 


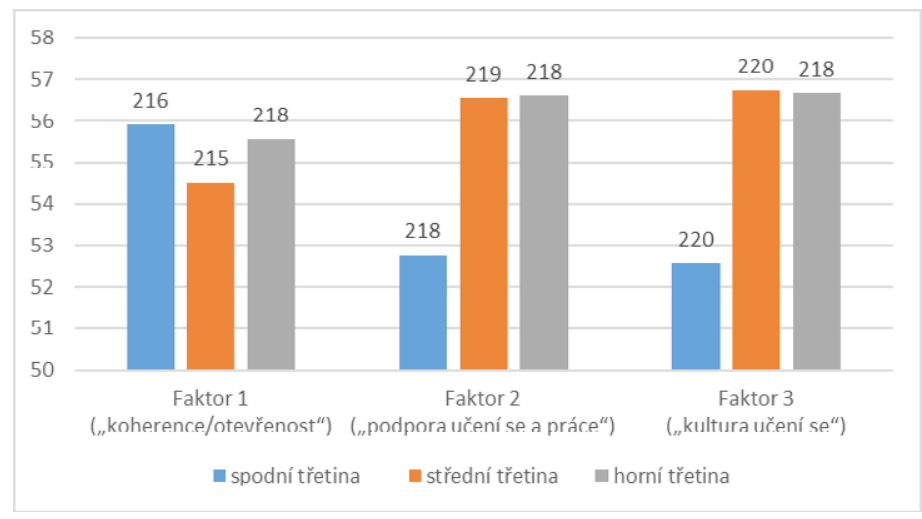

\section{Obrázek 7 \\ Skóre implementačního chování jednotlivcu pracujücich v rüzných organizačnich prostredich}

Poznámky: Data z individuální databáze Innova2 a organizační databáze Innova1. Škála vyjadřuje hodnotu skóre implementačního chování jednotlivců (škála 1-100). Čísla uvedená nad sloupci vyjadřují počet př́padů. Rozdíly mezi spodní a střední třetinou faktorů „podpora učení se a práce“ a „kultura učení se“ jsou statisticky významné.

Souhrnně můžeme říci, že inovační chování a aktivita jednotlivců (učitelů, školitelů) není nezávislá na dynamické kapacitě jejich pracoviště (školy, vysokoškolské katedry), nicméně vazba mezi nimi není př́liš silná. Ze třech faktorů dynamické kapacity pracoviště vykazují pouze dva (podpora práce / učení se a úroveň kultury učení se) významnou korelaci s charakteristikami inovačního chování jednotlivců. Zdá se, že jeden z faktorů (vnitřní koherence a otevřenost směrem ven) nevykazuje významnou korelaci s individuálními charakteristikami inovačního chování. Organizace (pracoviště) s vyšší hodnotou tohoto faktoru kombinují zdůrazňování společných interních hodnot (koherence) s pozitivním přístupem ke spolupráci s okolním prostředím (otevřenost). Tyto organizace se vyznačují vyšší mírou inovační aktivity na úrovni organizace, ale nezdá se, že by se jejich zaměstnancům dostávalo zvláštní podpory individuálních inovačních projevů.

\section{Individuální inovační chovánílaktivita a obecný profil organizace}

Obecný organizační profil sledovaných vzdělávacích jednotek byl určen na základě zjednodušené a upravené verze nástroje pro hodnocení organizační kultury (Organizational Culture Assessment Instrument - OCAI), který vytvořili Cameron a Quinn (2006). Náš nástroj obsahuje pouze 16 položek. Faktorová analýza hlavních komponent (s rotací varimax) provedená na 
organizační databázi ${ }^{8}$ vyústila ve dva faktory s vlastními čísly vyššími než 1 , objasňující $61 \%$ variability. Faktor 1 byl interpretován jako lidé „pracující v efektivně fungujících, demokratických a stabilních organizacích“ (označeno jako „efeketivita“). Faktor 2 byl interpretován jako lidé „pracující v dynamických, inovativních, na výkon orientovaných organizacích“" (označeno jako „dynamismus"). Faktorová skóre, podobně jako proměnné dynamické kapacity, byla za účelem usnadnění porovnání převedena na škálu 1-100 a posloužila jako ukazatele profilu organizačního prostředí, ve kterém jednotliví respondenti pracují. V tomto př́padě jsme opět jako nástroj charakterizace jednotlivců použili data za organizaci.

Na základě dvou nezávislých proměnných organizačního profilu lze rozlišit čtyři různé typy pracovišt', k jejichž popisu opět použijeme čtyři metafory (viz obrázek 8). Stojí za povšimnutí, že osoby pracující v organizacích typu „raketa“ (vyznačují se jak vysokým stupněm efektivity, tak také dynamismu, včetně inovativnosti) vykazují mírně nižší míru inovační aktivity (rozdíl není statisticky významný) než osoby v organizacích typu „kluzák““ (vyznačují se vysokým stupněm dynamismu a inovativnosti, ale nižší mírou efektivity a stability).

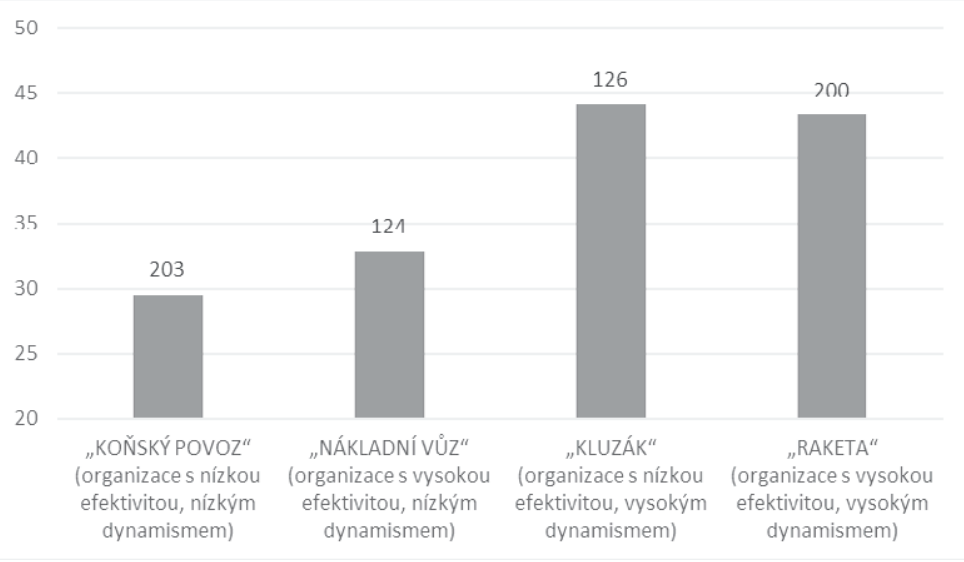

Obrázek 8

Úroveň inovačni aktivity jednotlivcu (skóre CII) pracujicich v rüzných organizačnich prostréeích

Poznámky: Data z individuální a organizační databáze Innova2. Škála vyjadřuje hodnotu skóre indexu CII (škála 1-100). Čísla uvedená nad sloupci vyjadřují počet případů. Rozdíly mezi hodnotami, vyjma rozdílů mezi dvěma nejvyššími hodnotami, jsou statisticky významné.

$8 \quad$ Pro účely této analýzy byly zahrnuty pouze organizace jednotlivců, kteří prezentovali jednu ze svých konkrétních inovací. Do faktorové analýzy bylo zahrnuto celkem 389 organizací. 
Osoby s jednotlivými vzorci inovačního pracovního chování (IWB) jsou ve čtyřech skupinách organizací s odlišnými organizačními profily zastoupeny odlišně. V organizacích vyznačujících se nízkou mírou efektivity i dynamismu („koňský povoz“) je mnohem vyšší zastoupení osob bez kreativní a implementační způsobilosti („,rutinéři“) než v ostatních třech typech organizací (zvlášt’ v organizaci typu „raketa“). A platí to také obráceně: poměr „,inovátorư “ je výrazně vyšší v organizacích typu „raketa“ a „kluzák“ než v těch, které jsme obrazně označili jako „koňský povoz“ nebo „nákladní vưz“ (viz obrázek 9).

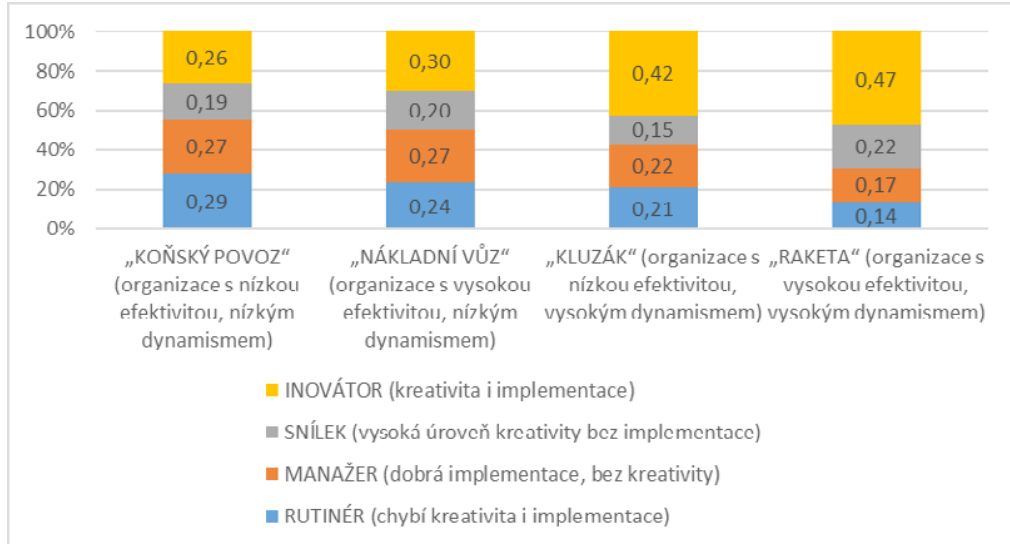

Obrázek 9

Rozdèlení jednotlivci nálě̌ejicicich k ruizným kategoriím IWB v rámci čtyř skupin organizací s rüznými organizačnimi profily

Poznámky: Data z individuální a organizační databáze Innova2.

Předpokládáme, že pozitivní vztah mezi inovačním pracovním chováním (IWB) a vzorci organizačního profilu odráží výsledek komplexních vývojových procesů. Typ instituce „koňský povoz“ poskytuje méně prríznivé prostředí pro „,inovátory“ než organizace typu „raketa“: „,inovátoři““ se pravděpodobně snaží tento typ instituce opustit a najít si pracovní uplatnění v organizaci, která má blíže k typu „raketa“. Z toho vyplývá, že pokud „inovátořic“ opustí organizace typu „koňský povoz“, šance těchto organizací na rozvoj směrem k opačnému pólu se tím zmenšují. Tímto způsobem mohou vznikat sebezesilující procesy, v rámci nichž se nízké stává nižším a vysoké vyšším. Tento pohled můžeme ilustrovat jednou hodnotou: zatímco více než 70 \% jednotlivců pracujících v organizacích typu ,raketa“ zvolilo na otázku, jak často se v posledních deseti letech zúčastnili dalšího vzdělávání, v rámci něhož „,se naučili nové způsoby zlepšování svého výkonu“, odpověd” „často“ nebo „velmi často“, podíl osob s těmito odpověd'mi byl v organizacích typu „koňský povoz“ méně než 58 \%. 
Skupiny vadelávacich jednotek vykazujici rozdilné inovačni charakteristiky Data týkající se individuální inovační aktivity / individuálního inovačního chování a organizačních charakteristik umožňují použít pro účely rozlišení konkrétních typů kombinací analýzy s více proměnnými. $\mathrm{V}$ tomto př́padě byla použita dvoustupňová shluková analýza s předběžným určením počtu skupin $(\mathrm{N}=4)$. Šest organizačních proměnných, které byly ve shlukové analýze použity jako vstupní proměnné, jsou totožné s proměnnými použitými $\mathrm{v}$ předchozích oddílech:

(1) Inovační aktivita na úrovni organizace

(2) Organizační dynamismus (učící se organizace)

2a: Koherence/otevřenost

2b: Podpora učení se a práce

2c: Kultura učení se

(3) Organizační profil

3a: Efektivita

3b: Dynamismus

Největší počet jednotek $(\mathrm{N}=158)$ připadá na skupinu, pro kterou jsou charakteristické následující znaky: (1) průměrná úroveň inovační aktivity na úrovni organizace; (2) poměrně vysoká úroveň hodnot reprezentujících učící se organizaci, zejména koherence/otevřenost, a nižší hodnoty, pokud jde o kulturu učení se a podporu učení se a práce; a (3) organizační profil vyznačující se velmi vysokou úrovní efektivity a mnohem nižší, ale stále poměrně vysokou úrovní dynamismu. Jedná se o dobře organizované, efektivní vzdělávací jednotky, které nevykazují nijak zvlášt' vysokou úroveň dynamismu a neobsadily ani přední příčky v inovační aktivitě. Můžeme je označit za efektivní školy držicí se běžných postupui. Nejmenší počet jednotek $(\mathrm{N}=58)$ pak připadá na skupinu, v níž vzdělávací jednotky vykazují tyto znaky: (1) velmi vysoká úroveň inovační aktivity na úrovni organizace; (2) vysoká míra znaků učící se organizace s velmi vysokou úrovní kultury učení se, ale výrazně nižší úrovní podpory učení se a práce; a (3) organizační profil vyznačující se vysokou úrovní dynamismu a podstatně nižší úrovní efektivity. Z našich dat dále vyplývá, že tyto školy samy hodnotí svůj výkon vysoko: jejich ukazatele sebehodnocení výkonu jsou nejvyšší. Tyto jednotky bychom mohli popsat jako inovativní, dynamické, sobèstačné školy.

9 Na vnímání výkonu organizace, v níž působí, v porovnání s obdobnými organizacemi a také na to, jak vnímají dočasnou změnu výkonu, byli dotázáni vedoucí i zaměstnanci. Tvrzení související s výkonem v textu vychází z analýzy složených ukazatelů výkonu založených na uvedených dotazníkových položkách. 
Počet jednotek ve třetí a čtvrté skupině je podobný $(\mathrm{N}=90 ; \mathrm{N}=86)$. Tyto jednotky se podobají také úrovní inovační aktivity a svým organizačním profilem. Vyznačují se (1) nízkou úrovní inovační aktivity na úrovni organizace a (3) organizačním profilem s nízkou úrovní efektivity a dynamismu. Naproti tomu ale vykazují (2) velmi odlišné charakteristiky učící se organizace. V jedné $z$ těchto skupin školy poskytují velmi vysokou (nejvyšší) úroveň podpory učení se a práce svých zaměstnanců, hodnoty reprezentující kulturu učení jsou přitom ale nejnižší. $\mathrm{V}$ protikladu $\mathrm{k}$ nim školy $\mathrm{v}$ další skupině nabízejí velmi nízkou úroveň podpory učení se a práce zaměstnanců, ale dosahují relativně vysoké úrovně kultury učení se. Naše data vztahující se $\mathrm{k}$ sebehodnocení výkonu indikují nízkou úroveň výkonu v obou skupinách, přičemž nejnižší úroveň je ve skupině 3 . K popisu jednotek ve skupině 1 bychom mohli použít označení snaživí opozdilci a pro jednotky ve skupině 3 pak soběstační opozdilci.

$V$ těchto čtyřech skupinách můžeme pozorovat odlišné vzorce inovačního chování a inovační aktivity na úrovni jednotlivců. Jak je patrné z obrázku 10, nejvyššího skóre inovačního pracovního chování (IWB) jednotlivců dosáhly vzdělávací jednotky ve skupině efektivních škol držících se běžných postupů, ale skóre individuální inovační aktivity (CII) bylo nejvyšší ve skupině popsané jako inovativní, dynamické, soběstačné školy. Všechna skóre individuální inovační aktivity / individuálního inovačního chování jsou nejnižší ve skupině organizací typu soběstační opozdilci.

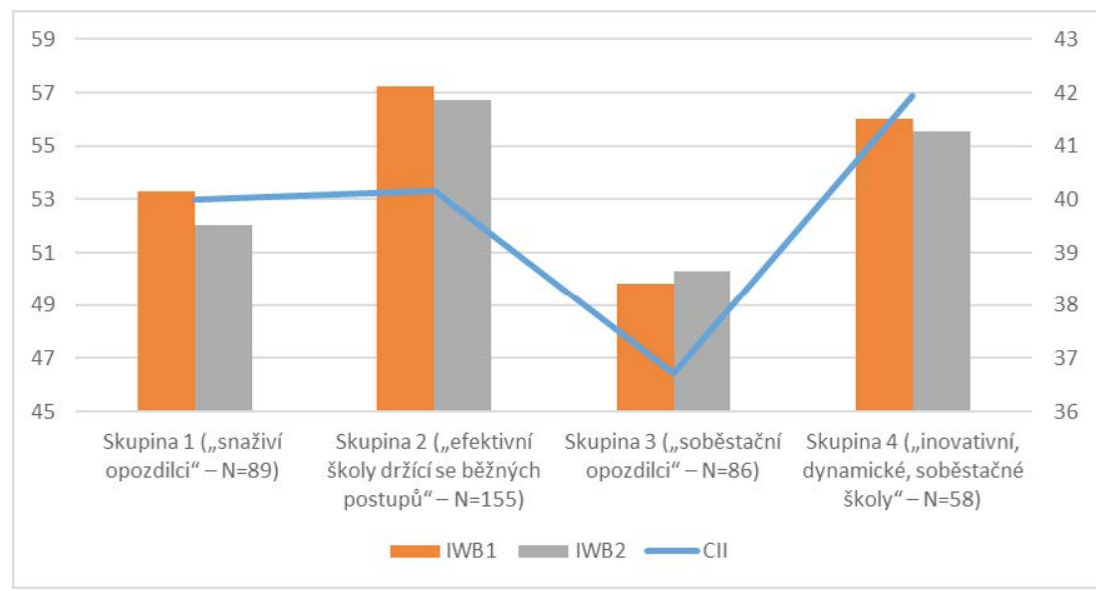

Obrázek 10

Prümèrná skóre individuálního inovačního chováni a individuální inovačni aktivity ve řtyrech skupinách vadélávacích jednotek.

Poznámky: Data z individuální databáze Innova2 a organizačních databází Innova1 a Innova2. Rozdíly ve skóre IWB mezi skupinou 1 a 2 jsou statisticky významné, zatímco rozdíly mezi skupinou 1 a 3 nikoli. Pokud jde o CII, jsou statisticky významné pouze rozdíly mezi skupinou 3 a 4. 
Rozlišení jednotlivých skupin by mohlo pomoci při plánování intervencí zacílených na zkvalitnění procesů, včetně prozkoumání stávající inovační kapacity organizací i jejich pracovníků. Další oblastí, pro kterou by tento postup mohl být užitečný, je sebehodnocení vzdělávacích organizací, jehož součástí je také identifikace silných a slabých stránek. Obecně se dá říci, že vyšší kapacita na úrovni organizace je prediktorem vyšší úrovně individuální inovační kapacity, avšak jak dokládají analýzy s více proměnnými, některé znaky organizace mohou být více podpůrné než jiné.

\section{Závěr}

Inovace vytvořené zaměstnanci v rámci jejich každodenní praxe hrají důležitou roli z hlediska zkvalitňování služeb. Pracovníci, kteří v reakci na výzvy, jež před ně staví pracovní realita, neustále přicházejí s novými řešeními, dosahují lepších výsledků než ti, kdo se jednoduše řídí běžnými postupy a standardními protokoly. $\mathrm{V}$ tomto ohledu se vzdělávací sektor zcela jistě neliší od ostatních veřejných sektorů. Jednotliví zaměstnanci (učitelé a školitelé) se liší co do schopností a ochoty inovovat. Někteří z nich vykazují výrazně vyšší úroveň inovační aktivity a více znaků inovačního pracovního chování než jiní.

Podobně jako $\mathrm{v}$ jiných sektorech veřejných služeb také ve vzdělávacím sektoru lze inovační aktivitu a inovační chování měřit pomocí průzkumů v oblasti inovací. Průzkumy inovací umožňují při sběru dat na individuální i organizační úrovni prozkoumat různé oblasti včetně vztahu mezi různými pracovními prostředími a inovační aktivitou a inovačním chováním jednotlivých zaměstnanců. $V$ tomto př́spěvku jsme využili analýzu tohoto vztahu $\mathrm{k}$ doložení analytického potenciálu průzkumů inovací ve vzdělávacím sektoru, zejména pokud se zkombinují data za pracoviště s daty za jednotlivé zaměstnance. Tento typ průzkumu skýtá celou řadu dalších analytických př́ležitostí, zvlášt' pokud se využije kombinace př́stupů zaměřených na subjekt a na objekt (přičemž první z nich se zaměřuje na aktéry inovací a druhý na inovace, které vytváří). Díky této perspektivě je např́íklad možné analyzovat vztah mezi intenzitou inovační aktivity a skutečnou hodnotou inovací (Halász \& Fazekas, 2020).

Průzkum zaměřený na inovace ve vzdělávacím sektoru provedený v rámci mad’arského výzkumného projektu s názvem Innova poskytl data na úrovni jednotlivců i organizací. Klíčovým předpokladem projektu Innova bylo, že inovační aktivitu a inovační chování lze zachytit pomocí stejných nástrojů ve všech dílčích složkách vzdělávacího systému od předškolního po postgraduální stupeň. $V$ tomto př́spěvku jsme použili data na úrovni jednotlivců a organizací za účelem zkoumání rozdílů v inovační aktivitě a inovačním chování učitelů a školitelů působících v různých pracovních prostředích. 
Analýzou byly zjištěny významné rozdíly v inovační aktivitě a inovačním chování mezi učiteli a školiteli zaměstnanými ve vzdělávacích institucích/ organizacích, které se vyznačují různými organizačními charakteristikami. Jako více inovativní se jeví pracovníci institucí/organizací, které (1) se vyznačují vyšší mírou inovační aktivity, (2) mají blíže tomu, co nazýváme učící se organizací, a (3) jsou efektivnější a dynamičtější. Na základě těchto organizačních znakủ lze rozlišit specifické skupiny vzdělávacích jednotek. Pracovníci organizací náležejících $\mathrm{k}$ těmto skupinám se vyznačují různou mírou inovační aktivity a inovačního chování. Data prezentovaná v tomto příspěvku mohou využít tvůrci intervencí rozvoje vzdělávacího sektoru: intervence lze využít efektivněji, je-li zohledněna inovační kapacita cílových jednotek.

\section{Literatura}

Arundel, A., Bloch, C., \& Ferguson, B. (2016a). Measuring innovation in the public sector. Australian Innovation Research Centre, University of Tasmania.

Arundel, A., Bowen-Butchart, D., Gatenby-Clark, S., \& Goedegebuure, L. (2016b). Management and service innovations in Australian and New Zealand universities. LH Martin Institute, University of Melbourne.

Balázs, É., Fazekas, Á., Fischer, M., Györi, J., Halász, G., Kovács, I. V., ... Wolfné Borsi, J. (2015). „Smart public education“. A recommendation to complement the national education sector innovation strategy [,Okos köznevelés“. Javaslat a Nemzeti Oktatási Innovációs Rendszer stratégiájának kiegészítésére.]. ELTE University.

Ball, S. J. (2012). The micro-politics of the school: Towards a theory of school organization. Routledge. https://doi.org/10.4324/9780203808733

Bess, K. D., Perkins, D. D., \& McCown, D. L. (2010). Testing a measure of organizationallearning capacity and readiness for transformational change in human services. Journal of Prevention \& Intervention in the Community, 39(1), 35-49. https://doi.org/10.1080/10852352. 2011.530164

Cameron, K. S., \& Quinn, R. E. (2006). Diagnosing and changing organizational culture: Based on the competing values framework. Jossey-Bass - Wiley.

De Jong, J. P., \& Den Hartog, D. N. (2008). Innovative work behavior: Measurement and validation. EIM Business and Policy Research, 8(1), 1-27.

Dunne, A., Patel, R., \& Souto Otero, M. (2014). Study on policies promoting innovative pedagogies that are effective in tackling low achievement in basic skills. Publications Office of the European Union.

Engeström, Y. (1999a). Activity theory and individual and social transformation. In Y. Engeström, R. Miettinen, \& R. L. Punamaki (Eds.), Perspectives on activity theory (s. 19-38). Cambridge University Press.

Engeström, Y. (1999b). Innovative learning in work teams: Analysing cycles of knowledge creation in practice. In Y. Engeström, R. Miettinen, \& R. L. Punamaki (Eds.), Perspectives on activity theory (s. 377-406). Cambridge University Press.

Fazekas, Á. (2018). The impact of EU-funded development interventions on teaching practices in Hungarian schools. European Journal of Education, 53(3), 377-392. https://doi. org/10.1111/ejed.12295 
Fazekas, Á., Halász, G., \& Horváth, L. (2018). Innovations and innovation processes in the Hungarian education system [Innovációk és innovációs folyamatok a magyar oktatási rendszerben]. Educatio, 27(2), 247-264. https://doi.org/10.1556/2063.27.2018.2.7

Fraser, A. J. (2005). Teacher-led innovation and development to improve professional practice. The Winston Churchill Memorial Trust of Australia. https://www.churchilltrust.com.au/media/ fellows/Fraser_Andrew_2005.pdf

Fullan, M. (2011). Seminar series 204. Choosing the wrong drivers for whole system reform. Center for Strategic Education.

Goodwin, A. L. (2014). Perspectives on high performing education systems in Finland, Hong Kong, China, South Korea and Singapore: What lessons for the U.S.? In S. K. Lee, W. O. Lee, \& E. L. Low (Eds.), Educational policy innovations: Levelling up and sustaining educational achievement (s. 185-200), Springer.

Halász, G. (2018a). Measuring innovation in education: The outcomes of a national education sector innovation survey. European Journal of Education, 53(4), 557-573. https://doi. org/10.1111/ejed.12299

Halász, G. (2018b). Teacher learning and innovation: The case of Hungary. Př́spěvek připravený v rámci „Belt and Road Education Research Project“, 2017, the Chinese National Institute of Educational Sciences.

Halász, G., \& Fazekas, Á. (2020). Who is innovating and how in the education sector? Combining the subject and the object approaches in an education sector innovation survey. Forthcoming.

Horváth, L. (2017). Organisational learning and innovation in the subsystems of the Hungarian education system [A szervezeti tanulás és az innováció összefüggései a magyar oktatási rendszer alrendszereiben]. Neveléstudomány, 5(4), 44-66. https://doi.org/10.21549/ NTNY.20.2017.4.3

Horváth, L., \& Halász, G. (2017). Innovation in the Hungarian educational sector. In P. Vrgović, A. Pilav-Velić, \& C. Dreher (Eds.), DSCIM - 2017 1st Doctoral students conference on innovation management: Proceedings (s. 63-76). Faculty of Technical Sciences.

Høyrup, S. (2012). Employee-driven innovation: A new phenomenon, concept and mode of innovation. In S. Høyrup, M. Bonnafous-Boucher, C. Hasse, M. Lotz, \& K. Møller (Eds.), Employee-driven innovation. A new approach (s. 3-34). Palgrave Macmillan.

Cheng, E. C., \& Lo, M. L. (2013). Learning study: Its origins, operationalisation, and implications. OECD Publishing.

Marsick, V. J., \& Watkins, K. E. (2003). Demonstrating the value of an organization's learning culture: The dimensions of the learning organization questionnaire. Advances in Developing Human Resources, 5(2), 132-151. https://doi.org/10.1177/1523422303005002002

Melkas, H., \& Harmaakorpi, V. (2012). Introduction. In H. Melkas \& V. Harmaakorpi (Eds.), Practice-based innovation: Insights, applications and policy implications (s. 1-13). Springer.

Messmann, G., \& Mulder, R. H. (2012). Development of a measurement instrument for innovative work behaviour as a dynamic and context-bound construct. Human Resource Development International, 15(1), 43-59. https://doi.org/10.1080/13678868.2011.646894

NESTA. (2007). Hidden innovation. How innovation happens in six 'low innovation' sectors. NESTA. https://www.researchgate.net/publication/318431538_Hidden_Innovation_in_the_ Creative_Industries

NIERD. (2011). Strategy proposal for the development of the Hungarian national education sector innovation system. National Institute for Educational Research and Development. http://ofi.hu/ sites/default/files/ofipast/2011/05/8.1.-Vezetoi_osszefoglalo-EN.pdf 
Nilsen, P., \& Ellström, P. E. (2012). Fostering practice-based innovation through reflection at work. In H. Melkas \& V. Harmaakorpi (Eds.), Practice-based innovation: Insights, applications and policy implications (s. 155-172). Springer.

OECD. (2008). Handbook on constructing composite indicators methodology and user guide. OECD Publishing.

OECD. (2014). Measuring innovation in education: A new perspective, educational research and innovation. OECD Publishing.

OECD. (2016). Innovating education and educating for innovation. The power of digital technologies and skills. OECD Publishing.

OECD. (2017). Measuring innovation in education. A journey to the future. OECD Publishing.

OECD/Eurostat. (2018). Oslo manual 2018: Guidelines for collecting, reporting and using data on innovation. The measurement of scientific, technological and innovation activities (4. vyd.). OECD Publishing.

Shirley, D. (2016). How to lead educational change. Journal of Educational Change, 17(3), 281-285. https://doi.org/10.1007/s10833-016-9281-9

Smirnov, I. (2017). Identifying factors associated with the survival and success of grassroots educational innovations. In A. M. Sidorkin \& M. K. Warford (Eds.), Reforms and innovation in education (s. 85-98). Springer.

Song, J. H., Chermack, T. J., \& Kim, W. (2013). An analysis and synthesis of DLOQ-based learning organization research. Advances in Developing Human Resources, 15(2), 222-239. https://doi.org/10.1177/1523422313475995

Tan, C. (2016). Teacher agency and school-based curriculum in China's non-elite schools. Journal of Educational Change, 17(3), 287-302. https://doi.org/10.1007/s10833-016-9274-8

Vincent-Lancrin, S., Urgel, J., Kar, S., \& Jacotinet, G. (2019). Measuring innovation in education 2019: What has changed in the classroom? OECD Publishing.

Yang, B., Watkins, K. E., \& Marsick, V. J. (2004). The construct of the learning organization: Dimensions, measurement, and validation. Human Resource Development Quarterly, 15(1), 31-55. https://doi.org/10.1002/hrdq.1086

\section{Kontakt na autora}

Gábor Halász

Univerzita Loránda Eötvöse v Budapešti

E-mail: halasz.gabor@ppk.elte.hu

\section{Corresponding author}

Gábor Halász

ELTE University, Budapest

E-mail: halasz.gabor@ppk.elte.hu 
